\title{
Karakterisasi 13 Genotipe Terung (Solanum melongena L.) Koleksi Pusat Kajian Hortikultura Tropika (PKHT)
}

\section{Characterization of 13 Genotype Eggplant (Solanum melongena L.) Collected by Center for Tropical Horticulture Studies}

\author{
Isyfi Syaufi Nafilah ${ }^{1}$, Roedhy Poerwanto ${ }^{1,2}$, Darda Efendi ${ }^{1,2^{*}}$ \\ ${ }^{1}$ Departemen Agronomi dan Hortikultura. Fakultas Pertanian. Institut Pertanian Bogor (Bogor Agricultural University). \\ Jalan Meranti. Kampus IPB Dramaga. Bogor. 16680. Indonesia. \\ ${ }^{2}$ Pusat Kajian Hortikultura Tropika, Lembaga Penelitian dan Pengabdian pada Masyarakat Institut Pertanian Bogor, \\ Jl. Raya Pajajaran, Kampus IPB Baranangsiang, Bogor, Indonesia
}

Diterima 11 Mei 2018/Disetujui 11 Juni 2018

\begin{abstract}
Developing of eggplant variety is necessary to increase the national production. This research aims to obtain horticulture characters information from several eggplant genotype collected by PKHT which potential to develop become new variety. Observed genotype of this research there were GJ, 2016-056, 2016-076, 2016-084, 2016-002, 2016-004, 2016-005, 2016008, 2016-011, 2016-015, 2016-039, 2016-080, 2016-026, and two other variety as control there were Jafana and Pipit. This research used Randomized Complete Block Design single factor with four repetition. Result of qualitative character observation at germination phase, plant growth, stem, leaves, flower and fruit showed diversity. Result of quantitative character observation showed diversity. Genotype 2016-026, 2016-080, 2016-084, 2016-004, and 2016-015 have higher weight of fruit per plant than Jafana as control. Genotype 2016-002 has higher weight of fruit per plant than Pipit as control. Genotype which have less level of bacterial wilt disease were 2016-080, 2016-015, and 2016-002.
\end{abstract}

Keywords : bacterial wilt, diversity, qualitative, quantitative

\section{ABSTRAK}

Perakitan varietas terung perlu dilakukan untuk meningkatkan produksi dalam negeri. Penelitian ini bertujuan untuk memperoleh informasi karakter-karakter hortikultura dari beberapa genotipe terung koleksi PKHT yang potensial untuk dikembangkan menjadi varietas baru. Genotipe yang diamati pada penelitian ini adalah GJ, 2016-056, 2016-076, 2016-084, 2016-002, 2016-004, 2016-005, 2016-008, 2016-011, 2016-015, 2016-039, 2016-080, 2016-026, dan dua varietas sebagai pembanding yaitu Jafana dan Pipit. Penelitian ini menggunakan rancangan kelompok lengkap teracak faktor tunggal dengan empat ulangan. Hasil pengamatan karakter kualitatif pada fase kecambah, pertumbuhan tanaman, batang, helai daun, bunga dan buah menunjukkan keragaman. Hasil pengujian karakter kuantitatifjuga menunjukkan adanya keragaman. Genotipe 2016-026, 2016-080, 2016-084, 2016-004, dan 2016-015 memiliki bobot buah per tanaman yang lebih tinggi dibandingkan dengan varietas pembanding Jafana. Genotipe 2016-002 juga memiliki bobot buah per tanaman yang lebih tinggi dibandingkan varietas Pipit. Genotipe yang mengalami tingkat kejadian penyakit layu bakteri terendah adalah 2016080, 2016-015, dan 2016-002.

Kata kunci : keragaman, kualitatif, kuantitatif, layu bakteri

\section{PENDAHULUAN}

Terung dianggap berasal dari India, tempat domestifiksi utama kultivar terung berbuah besar, dan tempat bentuk liar tanaman ini masih ditemukan. Wilayah Bangladesh dan Myanmar (dulunya perbatasan India-Burma) dipercaya

\footnotetext{
* Penulis untuk korespondensi. e-mail: dardaefendi@yahoo.com
}

sebagai pusat keragaman terung. Terung adalah anggota genus Solanum, yang terdiri atas lebih dari 1.000 spesies. Terung adalah tanaman tahunan berumur pendek di daerah tropika, sedangkan di wilayah iklim sedang dibudidayakan sebagai tanaman setahun (Rubatzky dan Yamaguchi, 1999). Menurut Wahyudi (2011), terung dapat tumbuh pada ketinggian tempat 100-800 mdpl dengan $\mathrm{pH}$ optimal 5.5-5.8 dan tekstur tanah lempung sampai lempung berpasir yang mengandung bahan organik dan topsoil tebal. 
Terung merupakan sayuran yang popular di wilayah Cina, India, Jepang, dan banyak negara Mediterania, (Rubatzky dan Yamaguchi, 1999). Terung dikenal di Indonesia dan dikonsumsi oleh masyarakat luas karena mempunyai gizi dan manfaat yang baik bagi kesehatan. Menurut USDA (2016), terung mengandung serat yang tinggi dan gizi tambahan seperti kalium (229 mg $\left.100 \mathrm{~g}^{-1}\right)$, magnesium (14 mg $\left.100 \mathrm{~g}^{-1}\right)$, asam folat $\left(22 \mu \mathrm{g} 100 \mathrm{~g}^{-1}\right)$, vitamin B6 $\left(0.084 \mathrm{mg} 100 \mathrm{~g}^{-1}\right)$ dan A $\left(1 \mu \mathrm{g} 100 \mathrm{~g}^{-1}\right)$. Manfaat terung yang diketahui masyarakat luas akan berpengaruh terhadap permintaan pasar. Indonesia merupakan salah satu negara yang memproduksi terung. Berdasarkan data Ditjen Hortikultura (2015), produksi terung pada tahun 2014 mencapai 557.040 ton dan memberikan kontribusi $4.67 \%$ terhadap peningkatan produksi sayuran di Indonesia. Selain itu, luas panen terung pun meningkat, dari 50.718 ha pada tahun 2013, menjadi 50.875 ha pada tahun 2014 . Meskipun produksi terung di Indonesia meningkat, namun prodiktivitsnya masih jauh rendah jika dibandingkan dengan produktivitas terung di China. Menurut data FAO (2016), produktivitas terung di Indonesia pada tahun 2014 adalah 10,95 ton $\mathrm{ha}^{-1}$, sedangkan di China mencapai 36.73 ton ha-1.

Meningkatnya pertumbuhan penduduk mengakibatkan alih fungsi lahan pertanian menjadi lahan non-pertanian pun meningkat. Menurut data BPS (2014), luas lahan pertanian (sawah) di Indonesia mengalami penurunan dari 8.127.264 ha pada tahun 2012 menjadi 8.112.103 ha pada tahun 2013 . Hal tersebut mengakibatkan peningkatan produksi melalui perluasan area tanam sulit untuk dilakukan. Peningkatan produksi dapat dilakukan melalui perakitan varietas unggul. Peran varietas unggul dalam meningkatkan produktivitas tanaman mencapai 65\%. Perakitan varietas unggul merupakan tujuan dari pemuliaan tanaman. Langkah awal bagi setiap program pemuliaan tanaman adalah koleksi berbagai genotipe atau plasma nutfah. Setelah itu, setiap genotipe di karakterisasi untuk selanjutnya dapat diseleksi genotipe dengan karakter yang akan dikembangkan (Syukur et al., 2012).

Karakterisasi merupakan tahap kedua dalam kegiatan pemuliaan tanaman setelah koleksi plasma nutfah. Karakterisasi merupakan proses identifikasi karakterkarakter pada tanaman. Karakter-karakter tertentu pada tanaman seperti warna bunga, bentuk polong, dan warna polong dikendalikan oleh gen sederhana (satu atau dua gen) dan tidak atau sedikit sekali dipengaruhi lingkungan. Karakter ini disebut dengan karakter kualitatif. Karakter yang mempunyai nilai ekonomi dan agronomi sangat penting seperti daya hasil, ukuran tanaman, ketahanan kekeringan, ketahanan rebah, dan kualitas hasil umumnya dipengaruhi oleh banyak gen serta dipengaruhi lingkungan. Karakter seperti ini disebut dengan karakter kuantitatif (Syukur et al., 2012).

Pusat Kajian Hortikultura Tropika (PKHT) IPB telah melakukan eksplorasi plasma nutfah tanaman terung. Dalam rangka pengembangan varietas baru terung yang lebih adaptif terhadap perubahan iklim dan lingkungan, maka genotipegenotipe terung koleksi PKHT perlu diuji. Oleh karena itu, diperlukan karakterisasi untuk memperoleh informasi masing-masing karakter dari genotipe tersebut. Penelitian ini bertujuan untuk memperoleh informasi karakter-karakter Hortikultura dari beberapa genotipe terung koleksi PKHT yang potensial untuk dikembangkan menjadi varietas baru.

\section{BAHAN DAN METODE}

Penelitian dilaksanakan di Kebun Percobaan IPB Tajur, Bogor pada bulan Januari sampai dengan Juni 2017. Bahan yang digunakan dalam penelitian adalah 13 genotipe tanaman terung hasil eksplorasi yaitu GJ (G1), 2016-056 (G2), 2016-076 (G3), 2016-084 (G4), 2016-002 (G5), 2016-004 (G6), 2016-005 (G7), 2016-008 (G8), 2016-011 (G9), 2016-015 (G10), 2016-039 (G11), 2016-080 (G12), 2016-026 (G13), dan dua varietas sebagai pembanding yaitu Jafana (G14) dan Pipit (G15). Bahan lain yang digunakan adalah tray semai, mulsa plastik, media semai, ajir, pupuk kandang, pupuk urea, SP36, KCl, pupuk NPK mutiara, kapur dolomit, furadan, pestisida, dan fungisida. Alat yang digunakan adalah alat-alat pertanian seperti pada umumnya, alat tulis, dan alat-alat untuk dokumentasi.

Rancangan percobaan yang digunakan adalah rancangan kelompok lengkap teracak (RKLT) faktorial dengan menggunakan satu faktor yaitu genotipe. Terdapat 13 genotipe terung dan dua varietas pembanding yang diteliti. Setiap genotipe terdiri dari 4 ulangan, sehingga terdapat 60 satuan percobaan dengan setiap satuan percobaan terdiri atas 10 tanaman, sehingga jumlah tanaman seluruh satuan percobaan 600 tanaman.

Penyemaian dan pembibitan dilakukan selama empat minggu. Penyemaian dilakukan dalam wadah tray dengan menggunakan media semai pupuk kandang dan tanah 1:1. Persiapan lahan dilakukan dua minggu sebelum penanaman bibit terung. Kegiatan persiapan lahan meliputi penggemburan tanah, pembuatan bedengan, pemberian pupuk kandang dan pupuk NPK dasar, serta pemasangan mulsa plastik. Penanaman dilakukan setelah bibit memiliki 4-6 helai daun pada bedengan yeng telah dibagi menjadi 8 petak. Setiap petak terdiri dari dua baris tanaman, dan setiap baris terdapat lima tanaman, sehingga terdapat 10 tanaman pada satu petak. Jarak tanam dalam baris adalah 30 $\mathrm{cm}$ sedangkan jarak tanam antar baris $50 \mathrm{~cm}$. Penyulaman dilakukan seminggu setelah penanaman.

Pemeliharaan tanaman dilakukan sejak pembibitan hingga pemanenan. Kegiatan pemeliharaan meliputi penyiraman, pemupukan, pemangkasan, penyiangan gulma, dan pengendalian hama penyakit tanaman. Penyiraman dilakukan dua kali sehari selama proses penyemaian, dan satu kali sehari setelah penanaman di lahan. Pemupukan susulan dilakukan setelah tanaman berumur 2 MST. Pemangkasan tunas adventif bertujuan untuk mengoptimalkan penggunaan hasil fotosintat oleh cabang utama. Penyiangan dilakukan pada gulma yang tumbuh disekitar tanaman dengan cara manual menggunakan tangan atau kored. Pengendalian hama dan penyakit tanaman dilakukan secara manual dan kimia. Pemanenan dilaksanakan apabila buah terung telah siap panen sesuai dengan kriteria pasar atau penen muda. 
Pengamatan dilakukan terhadap 5 tanaman contoh pada setiap petak percobaan yang dipilih secara acak. Karakter yang diamati meliputi karakter kualitatif dan karakter kuantitatif. Peubah yang diamati berdasarkan panduan pengamatan individual (PPI) yang dikeluarkan oleh Pusat Perlindungan Varietas Tanaman (PPVT) Departemen Pertanian Republik Indonesia (2007). Data diuji dengan analisis uji-F menggunakan perangkat lunak SAS (Statistical Analysis system). Hasil uji-F yang menunjukkan perbedaan nyata diuji lanjut dengan menggunakan Duncan Multiple Range Test (DMRT) pada taraf 5\%.Persentase kejadian penyakit menurut Rizky (2013) dihitung menggunakan rumus :

$$
\mathrm{KP}=\mathrm{n} \times \mathrm{N}^{-1} \times 100 \%
$$

Keterangan $: \mathrm{KP}=$ kejadian penyakit, $\mathrm{n}=$ jumlah tanaman yang terserang, $\mathrm{N}=$ jumlah seluruh tanaman contoh yang diamati.

\section{HASIL DAN PEMBAHASAN}

\section{Kondisi Umum}

Penelitian dilaksanakan di Kebun Percobaan Tajur, Pusat Kajian Hortikultura Tropika, Lembaga Penelitian dan Pengabdian kepada Masyarakat (PKHT LPPM IPB) yang memiliki ketinggian tempat $\pm 250 \mathrm{~m}$ diatas permukaan laut dengan kondisi pH tanah 5 (Khasanah, 2013). Curah hujan dari bulan Januari sampai Mei 2017 berkisar antara 176-529 mm dengan kelembaban dan suhu rata-rata berturut-turut
$85 \%$ dan $25.82^{\circ} \mathrm{C}$ (BMKG, 2017). Persemaian dilaksanakan pada Januari-Februari 2017 di dalam tray yang ditempatkan pada rak penyemaian. Daya tumbuh rata-rata tanaman terung pada setiap genotipe berkisar 44.4-100\%. Hama pada fase persemaian adalah kumbang pemakan daun Aulacophora sp.

Hama yang menyerang setelah pindah tanam adalah keongdanbekicot(Achatinafulica)yangmenyebabkanbatang patah, sehingga dilakukan penyulaman dan pembumbunan hingga 2 MST. Hama lain yang menyerang adalah jangkrik, belalang, kumbang pemakan daun (Epilachna sp.), kutu putih, kepik, dan lalat buah. Hal ini sesuai dengan penelitian Rizky (2013), organisme pengganggu tanaman (OPT) golongan hama yang ditemukan pada tanaman terung antara lain Epilachna sp. (Coleoptera: Coccinellidae), Empoasca sp. (Hemiptera: Cicadellidae), Valanga spp. (Orthophtera: Acrididae), Acherontia sp. (Lepidoptera: Sphingidae), Bactrocera spp. (Diptera: Tephritidae), Mictislongicornis (Hemiptera: Coreidae) dan Aulacophora spp. (Coleoptera: Chrysomelidae).

Pada fase generatif ditemukan gejala serangan penyakit layu bakteri yang disebabkan Ralstonia solanacearum dengan persentase yang sangat tinggi. Selain itu, penyakit lain yang menyerang adalah busuk buah (Phomopsis sp), antraknosa (Colletotrichum sp.), dan bercak daun (Alternaria sp.). Berdasarkan hasil penelitian Rizky (2013) terdapat kesamaan penyakit yang ditemukan antara lain bercak daun (Alternaria sp.), busuk buah (Phomopsis sp.), antraknosa (Colletotrichum sp.), dan layu bakteri (Ralstonia solanacearum).

Tabel 1. Keragaman karakter kualitatif pada hipokotil kecambah, batang, helai daun, dan bunga

\begin{tabular}{lccccccccc}
\hline Genotipe & IAHK & IAB & UHD & LTHD & UD & WB & JB & UB \\
\hline GJ & Sangat kuat & Sangat kuat & Kecil & Lemah & Tumpul & Ungu terang & Lebih dari tiga & Kecil \\
2016-056 & Tidak ada & Sangat lemah & Besar & Kuat & Runcing & Ungu sedang & Lebih dari tiga & Kecil \\
$2016-076$ & Tidak ada & Kuat & Kecil & Lemah & Tumpul & Ungu terang & Lebih dari tiga & Kecil \\
2016-084 & Sangat lemah & Sedang & Besar & Kuat & Runcing & Ungu terang & Lebih dari tiga & Sedang \\
2016-002 & Tidak ada & Tidak ada & Kecil & Kuat & Sedang & Putih & Lebih dari tiga & Kecil \\
2016-004 & Sangat kuat & Kuat & Besar & Sedang & Sedang & Ungu terang & Satu sampai tiga & Sedang \\
2016-005 & Lemah & Sedang & Sedang & Sedang & Tumpul & Ungu sedang & Lebih dari tiga & Sedang \\
2016-008 & Sangat lemah & Sedang & Besar & Kuat & Runcing & Ungu sedang & Satu sampai tiga & Sedang \\
2016-011 & Tidak ada & Kuat & Kecil & Kuat & Sedang & Ungu terang & Satu sampai tiga & Kecil \\
2016-015 & Sangat lemah & Sedang & Besar & Kuat & Runcing & Ungu sedang & Lebih dari tiga & Sedang \\
2016-039 & Sedang & Sedang & Besar & Kuat & Tumpul & Ungu sedang & Satu sampai tiga & Sedang \\
$2016-080$ & Sangat lemah & Sedang & Sedang & Kuat & Runcing & Ungu gelap & Lebih dari tiga & Besar \\
2016-026 & Sangat lemah & Kuat & Sangat besar & Kuat & Sedang & Ungu sedang & Satu sampai tiga & Besar \\
JAFANA & Sangat lemah & Kuat & Sedang & Kuat & Runcing & Ungu sedang & Lebih dari tiga & Sedang \\
PIPIT & Tidak ada & Tidak ada & Sangat kecil & Kuat & Sedang & Putih & Lebih dari tiga & Kecil \\
\hline
\end{tabular}

Keterangan : $\mathrm{IAHK}=$ Intensitas antosianin hipokotil kecambah, IAB $=$ intensitas antosianin batang, UHD $=$ Ukuran helai daun, LTHD $=$ lekukan tepi helai daun, $\mathrm{UD}=$ ujung daun, warna bunga, $\mathrm{JD}=$ jumlah bunga, $\mathrm{UB}=$ ukuran bunga 


\section{Karakter Kualitatif}

Karakter Kualitatif pada Hipokotil Kecambah, Batang, Helai Daun, dan Bunga

Hasil pengamatan karakter pewarnaan antosianin pada kecambah dan batang, serta karakter pada bunga menunjukkan adanya keragaman (Tabel 1). Pewarnaan antosianin hipokotil kecambah ditemukan keragaman tidak adanya pewarnaan antosianin pada genotipe 2016-056, 2016-076, 2016-002, 2016-011, dan PIPIT, sedangkan pewarnaan antosianin batang yang menunjukkan keragaman hanya pada genotipe 2016-002 dan PIPIT. Keragaman ukuran daun antara lain sangat besar, besar, sedang, kecil, dan sangat kecil. Keragaman lekukan tepi helai daun antara lain kuat, sedang, dan lemah. Keragaman bentuk ujung daun yang ditemukan di lapangan adalah tumpul, sedang, dan runcing.Keragaman warna bunga ditemukan pada genotipe 2016-002 dan PIPIT yang berwarna putih, sedangkan genotipe yang lainnya berwarna ungu. Jumlah bunga yang menunjukkan keragaman antara lain genotipe 2016-004, 2016-008, 2016-11, dan 2016-026. Keragaman ukuran bunga antara lain kecil, sedang, dan besar.

\section{Karakter Kualitatif pada Buah}

Hasil pengamatan terhadap karakter kualitatif buah menunjukkan adanya keragaman (Tabel 2). Keragaman bentuk buah yang ditemukan di lapangan adalah bundar (2016-076, 2016-002, dan PIPIT), bulat telur (2016-011), bulat telur sungsang (2016-005), pir (2016-026), club (2016-
056, 2016-080), dan silindris. Keragaman rasio panjang diameter ${ }^{-1}$ buah antara lain sangat kecil, kecil, besar, dan sangat besar. Karakter warna masak panen buah ditemukan keragaman yaitu hijau dan ungu dengan warna daging buah keputih-putihan dan kehijauan, sedangkan keragaman warna kulit masak fisiologisnya antara lain kuning, oranye coklat, dan coklat. Genotipe 2016-076, 2016-002, 2016-005, 2016011, dan varietas pembanding PIPIT memiliki garis-garis pada kulit buah, sedangkan genotipe lainnya tidak memiliki garis-garis. Keragaman kepadatan garis-garis dominan pada genotipe tersebut antara lain jarang dan padat. Keragaman duri pada kelopak ditemukan pada genotipe GJ dan 2016004 dengan jumlah duri berkisar 6-10 dan tergolong tipe sedang.

\section{Karakter Kuantitatif}

\section{Analisis Sidik Ragam}

Hasil analisis sidik ragam (Tabel 3) menunjukkan bahwa genotipe berpengaruh sangat nyata terhadap karakter kuantitatif tinggi tanaman, tinggi dikotomus, diameter batang panjang daun, lebar daun, panjang buah, diameter buah, panjang tangkai buah, dan bobot buah per tanaman. Nilai koefisien keragaman untuk karakter tersebut berkisar 8.9-18.48\%. Hasil analisis ragam pada peubah kuantitatif bobot per buah dan jumlah buah per tanaman menunjukkan bahwa perbedaan genotipe berpengaruh nyata pada taraf 5\% dengan nilai koefisien keragaman $38.03 \%$ dan $49.34 \%$. Selain itu, hasil analisis ragam pada karakter umur berbunga dan umur berbuah berpengaruh sangat nyata pada taraf $1 \%$,

Tabel 2. Keragaman karakter kualitatif pada buah

\begin{tabular}{|c|c|c|c|c|c|c|c|c|}
\hline Genotipe & BTK & RPD & WMP & WDB & WMF & KGG & IWK & DPK \\
\hline GJ & Silindris & Sangat besar & Ungu & Kehijauan & Coklat & Tidak ada & Sangat gelap & Sedang \\
\hline $2016-056$ & Club & Sangat besar & Hijau & Kehijauan & Kuning & Tidak ada & Sedang & Tidak ada \\
\hline $2016-076$ & Bundar & Sangat kecil & Ungu & Kehijauan & Kuning & Jarang & Gelap & Tidak ada \\
\hline $2016-084$ & Silindris & Sangat besar & Ungu & Keputih-putihan & Kuning & Tidak ada & Gelap & Tidak ada \\
\hline 2016-002 & Bundar & Sangat kecil & Hijau & Kehijauan & Kuning & Padat & Gelap & Tidak ada \\
\hline 2016-004 & Silindris & Sangat besar & Hijau & Kehijauan & Kuning & Tidak ada & Sedang & Sedang \\
\hline $2016-005$ & Bulat telur sungsang & Besar & Ungu & Kehijauan & Oranye coklat & Jarang & Sangat gelap & Tidak ada \\
\hline 2016-008 & Silindris & Sangat besar & Ungu & Keputih-putihan & Kuning & Tidak ada & Sangat gelap & Tidak ada \\
\hline 2016-011 & Bulat telur & Kecil & Hijau & Kehijauan & Kuning & Jarang & Sedang & Tidak ada \\
\hline $2016-015$ & Silindris & Sangat besar & Hijau & Kehijauan & Kuning & Tidak ada & Terang & Tidak ada \\
\hline 2016-039 & Silindris & Sangat besar & Hijau & Kehijauan & Kuning & Tidak ada & Sedang & Tidak ada \\
\hline $2016-080$ & Club & Sangat besar & Ungu & Keputih-putihan & Kuning & Tidak ada & Sangat gelap & Tidak ada \\
\hline $2016-026$ & Pir & Besar & Ungu & Kehijauan & Kuning & Tidak ada & Sangat gelap & Tidak ada \\
\hline JAFANA & Silindris & Sangat besar & Ungu & Keputih-putihan & Kuning & Tidak ada & Gelap & Tidak ada \\
\hline PIPIT & Bundar & Sangat kecil & Hijau & Kehijauan & Kuning & Padat & Gelap & Tidak ada \\
\hline
\end{tabular}

Keterangan : $\mathrm{BTK}=$ bentuk, RPD $=$ Rasio panjang terhadap diameter, WMP $=$ warna masak panen, WDP $=$ warna daging buah, Warna masak fisiologis, KGG = kerapatan garis-garis, IWK = intensitas warna kulit, DPK=duri pada kelopak 
tetapi penulis tidak mencantumkannya dalam tabel karena koefisien keragamannya bernilai nol, sedangkan kuadrat tengah untuk kedua karakter tersebut berturut-turut adalah 131.74 dan 90.23 .

Karakter Kuantitatif Tinggi Tanaman, Tinggi Dikotomus, Diameter Batang, Panjang Daun, Lebar Daun, Umur Berbunga, dan Umur Panen

Hasil pengujian karakter tinggi tanaman memiliki nilai tengah berkisar 29.38-68 cm (Tabel 4), dengan tinggi tanaman terendah adalah genotipe GJ, sedangkan tinggi tanaman tertinggi adalah genotipe 2016-011. Berdasarkan panduan pengamatan individual PPVT (2007), genotipe 2016-011 dan 2016-080 termasuk terung dengan tinggi tanaman sedang yaitu berkisar antara 60-100 cm. Genotipe lainnya termasuk kategori terung dengan tinggi tanaman pendek, berkisar $30-59 \mathrm{~cm}$. Beberapa genotipe terung seperti 2016-008, 2016-011, dan 2016-080 memiliki tinggi tenaman yang lebih rendah dibandingkan dengan hasil penelitian Widia (2016), tetapi masih termasuk dalam terung dengan tinggi tanaman sedang. Hal tersebut karena terdapat beberapa faktor luar dalam menentukan pertumbuhan dan produksi tanaman diantaranya adalah tanah, nutrisi, air, sinar matahari, temperature dan tinggi tempat (Ashari, 1995). Tanaman terung diharapkan memiliki tinggi bertipe sedang karena apabila tanaman bertipe tinggi mudah mengalami rebah.

Nilai tengah tinggi dikotomus berkisar antara 13.3$30.13 \mathrm{~cm}$ (Tabel 4). Genotipe terung yang memiliki nilai tengah tinggi dikotomus terendah adalah PIPIT yang hanya $13.3 \mathrm{~cm}$, sedangkan nilai tengah tinggi dikotomus tertinggi adalah genotipe 2016-080 yang mencapai $30.13 \mathrm{~cm}$. Nilai tengah untuk karakter diameter batang berkisar antara 0.99 $2.42 \mathrm{~cm}$. Genotipe GJ memiliki diameter batang terendah, yaitu $0.99 \mathrm{~cm}$, sedangkan genotipe 2016-023 memiliki

Tabel 3. Analisis Sidik Ragam

\begin{tabular}{clccc}
\hline No. & \multicolumn{1}{c}{ Peubah } & kk $(\%)$ & F hitung & Pr $>\mathrm{F}$ \\
\hline 1 & Tinggi tanaman $(\mathrm{cm})$ & 18.48 & $6.80 * *$ & $<.0001$ \\
2 & Tinggi dikotomus $(\mathrm{cm})$ & 14.15 & $6.45 * *$ & $<.0001$ \\
3 & Diameter batang $(\mathrm{cm})$ & 15.41 & $9.23 * *$ & $<.0001$ \\
4 & Panjang daun $(\mathrm{cm})$ & 10.34 & $14.99 * *$ & $<.0001$ \\
5 & Lebar daun $(\mathrm{cm})$ & 16.25 & $7.30 * *$ & $<.0001$ \\
6 & Panjang buah $(\mathrm{cm})$ & 13.32 & $30.63 * *$ & $<.0001$ \\
7 & Diameter buah $(\mathrm{cm})$ & 8.90 & $38.93 * *$ & $<.0001$ \\
8 & Panjang tangkai buah $(\mathrm{cm})$ & 18.21 & $11.53 * *$ & $<.0001$ \\
9 & Bobot buah pertanaman $(\mathrm{g})$ & 18.03 & $36.01 * *$ & $<.0001$ \\
10 & Bobot per buah $(\mathrm{g})$ & 38.03 & $3.90 *$ & 0.0575 \\
11 & Jumlah buah per tanaman & 49.34 & $5.64 *$ & 0.0287 \\
\hline
\end{tabular}

Keterangan : ** berpengaruh sangat nyata pada taraf $1 \%$; * berpengaruh nyata pada taraf 5\% diameter batang tertinggi yaitu $2.42 \mathrm{~cm}$. Tinggi dikotomus diharapkan pendek, sedangkan diameter batang diharapkan bernilai tinggi. Hal tersebut berkaitan dengan kekokohan tanaman. Hasil pengamatan untuk karakter panjang dan lebar daun memiliki nilai tengah berturut-turut berkisar antara 19.13-39.48 $\mathrm{cm}$ dan 15.14-31.56 cm. Nilai tengah terendah untuk panjang dan lebar daun dimiliki oleh genotipe Pipit. Nilai tengah tertinggi untuk panjang dan lebar daun dimiliki oleh genotipe 2016-026. Panjang dan lebar helai daun berkontribusi terhadap luas daun.Umur berbunga dari 15 genotipe terung yang diuji berkisar antara 40-59 HST, sedangkan umur panen berkisar antara 65-81 HST. Genotipe GJ mempunyai umur berbunga dan umur panen yang lebih cepat dibandingkan dengan genotipe lainnya.Genotipe 2016-008 dan 2016-039 memiliki umur berbunga paling lama. Genotipe 2016-056, 2016-004, 2016-005, dan 2016011 memiliki umur panen terlama. Umur berbunga dan umur panen diharapkan berumur genjah karena menentukan waktu berproduksi.

Karakter Kuantitatif Panjang Buah, Diameter Buah, Panjang Tangkai Buah, Bobot per Buah, Bobot Buah per Tanaman, dan Jumlah Buah per Tanaman

Hasil pengujian pada karakter panjang buah menunjukkan adanya keragaman (Tabel 5). Nilai tengah untuk panjang buah berkisar antara 5.76-27.4 cm. Terung berdasarkan nilai panjang buah dikelompokkan menjadi lima tipe yaitu sangat pendek $(<1 \mathrm{~cm})$, pendek (berkisar antara 1-2 $\mathrm{cm}$ ), sedang (berkisar antara 2-5 $\mathrm{cm}$ ), panjang (berkisar antara $6-10 \mathrm{~cm}$ ), dan sangat panjang apabila memiliki panjang lebih dari $10 \mathrm{~cm}$ (PPI PPVT, 2007). Genotipe 2016076 termasuk ke dalam tipe sedang, memiliki panjang buah dengan nilai tengah terendah yaitu $5.76 \mathrm{~cm}$. Genotipe 2016002, 2016-039, dan PIPIT termasuk ke dalam tipe panjang dengan nilai tengah panjang buah berturut-turut $8.10 \mathrm{~cm}$, $6.18 \mathrm{~cm}$, dan $7.23 \mathrm{~cm}$. Selain genotipe tersebut, genotipe yang lainnya termasuk tipe buah sangat panjang yang umumnya memiliki bentuk buah silindris, $c l u b$, dan pir.

Nilai tengah untuk diameter buah berkisar antara 3.54$9.9 \mathrm{~cm}$ (Tabel 5). Menurut panduan pengujian individual PPVT (2007) diameter buah berdasarkan nilai diameternya dikelompokkan menjadi lima tipe. Genotipe 2016-004 dan 2016-026 termasuk tipe besar dengan diameter buah berturut-turut $6.19 \mathrm{~cm}$ dan $9.9 \mathrm{~cm}$. Genotipe lainnya termasuk tipe sedang karena nilai tengah diameter buahnya berkisar antara 3.54-5.67 cm. Menurut Safei et al. (2014) jenis pupuk organik berpengaruh sangat nyata terhadap panjang buah dan diameter buah.

Karakter panjang tangkai buah yang diuji menunjukkan keragaman dengan nilai tengah 2.49-8.97 cm (Tabel 5). Genotipe 2016-011 memiliki panjang tangkai buah dengan nilai tengah terendah yaitu $2.49 \mathrm{~cm}$ dan tergolong ke dalam tipe panjang tangkai buah sedang. Genotipe 2016039 memiliki panjang tangkai buah dengan nilai tengah tertinggi yaitu $8.97 \mathrm{~cm}$ dan tergolong tipe panjang tangkai buah sangat panjang. Genotipe lainnya tergolong pada tipe panjang tangkai buah panjang karena nilai tengah panjang 
Tabel 4. Nilai pengamatan tinggi tanaman, tinggi dikotomus, diameter batang, panjang helai daun, lebar helai daun, umur berbunga dan umur panen

\begin{tabular}{|c|c|c|c|c|c|c|c|}
\hline Genotipe & $\mathrm{TT}(\mathrm{cm})$ & $\mathrm{TD}(\mathrm{cm})$ & $\mathrm{DB}(\mathrm{cm})$ & $\mathrm{PD}(\mathrm{cm})$ & $\mathrm{LD}(\mathrm{cm})$ & UB (HST) & UP (HST) \\
\hline GJ & $29.38 \mathrm{e}$ & 18.94ef & $0.99 f$ & $22.72 \mathrm{ef}$ & $17.25 \mathrm{ef}$ & $40 \mathrm{~h}$ & $65 f$ \\
\hline 2016-056 & $56.91 \mathrm{abc}$ & $20.06 \mathrm{def}$ & $1.87 \mathrm{~b}$ & $30.60 b c$ & $31.74 \mathrm{a}$ & $57 \mathrm{~b}$ & $81 \mathrm{a}$ \\
\hline $2016-076$ & $43.78 \mathrm{~cd}$ & $20.50 \mathrm{cdef}$ & $1.34 \mathrm{def}$ & $21.53 \mathrm{ef}$ & $18.44 \mathrm{def}$ & $50 \mathrm{~d}$ & $78 b$ \\
\hline $2016-084$ & $38.62 \mathrm{de}$ & $25.85 \mathrm{abc}$ & $1.36 \mathrm{cdef}$ & $30.04 \mathrm{bc}$ & $23.05 \mathrm{bcde}$ & $43 g$ & $78 b$ \\
\hline 2016-002 & $45.36 \mathrm{~cd}$ & $22.02 \mathrm{bcdef}$ & $1.31 \mathrm{ef}$ & $19.60 \mathrm{ef}$ & $16.93 \mathrm{ef}$ & $50 \mathrm{~d}$ & $70 \mathrm{e}$ \\
\hline 2016-004 & 46.10bcd & $23.16 \mathrm{bcdef}$ & $1.72 \mathrm{bcd}$ & $32.34 \mathrm{bc}$ & $25.21 b c$ & $50 \mathrm{~d}$ & $81 \mathrm{a}$ \\
\hline 2016-005 & $39.96 \mathrm{de}$ & $18.08 \mathrm{f}$ & $1.47 \mathrm{cde}$ & $27.54 \mathrm{~cd}$ & $21.87 \mathrm{cde}$ & $50 \mathrm{~d}$ & $81 \mathrm{a}$ \\
\hline 2016-008 & $59.56 \mathrm{ab}$ & $24.06 \mathrm{bcde}$ & $1.61 \mathrm{bcde}$ & $29.91 b c$ & $22.94 \mathrm{bcde}$ & $59 a$ & $78 \mathrm{~b}$ \\
\hline 2016-011 & $45.92 \mathrm{bcd}$ & $24.08 \mathrm{bcde}$ & $1.32 \mathrm{ef}$ & $24.13 \mathrm{de}$ & $20.33 \mathrm{cdef}$ & $52 \mathrm{c}$ & $81 \mathrm{a}$ \\
\hline $2016-015$ & $37.26 \mathrm{de}$ & $22.16 \mathrm{bcdef}$ & $1.51 \mathrm{bcde}$ & $30.13 b c$ & $24.37 \mathrm{bcd}$ & $46 \mathrm{e}$ & $74 c$ \\
\hline 2016-039 & $68.00 \mathrm{a}$ & $27.25 \mathrm{ab}$ & $1.74 b c$ & $33.94 b$ & $28.19 \mathrm{ab}$ & $59 \mathrm{a}$ & $70 \mathrm{e}$ \\
\hline 2016-080 & $62.41 \mathrm{a}$ & $30.13 a$ & $1.87 \mathrm{~b}$ & $28.97 \mathrm{c}$ & $21.04 \mathrm{cdef}$ & $44 \mathrm{f}$ & $71 d$ \\
\hline $2016-026$ & $56.16 \mathrm{abc}$ & $24.34 \mathrm{bcd}$ & $2.42 \mathrm{a}$ & $39.48 \mathrm{a}$ & $31.56 \mathrm{a}$ & $57 b$ & $78 b$ \\
\hline JAFANA & $43.82 \mathrm{~cd}$ & $24.10 \mathrm{bcde}$ & $1.37 \mathrm{cdef}$ & $28.17 \mathrm{~cd}$ & $21.92 \mathrm{cde}$ & $50 \mathrm{~d}$ & $78 b$ \\
\hline PIPIT & $31.90 \mathrm{de}$ & $13.3 \mathrm{~g}$ & $1.05 \mathrm{f}$ & $19.13 f$ & $15.14 \mathrm{f}$ & $50 \mathrm{~d}$ & $74 \mathrm{c}$ \\
\hline
\end{tabular}

Keterangan : Angka yang diikuti oleh huruf kecil yang sama pada kolom yang sama menunjukkan tidak berbeda nyata pada taraf uji $\alpha=5 \%$. TT = tinggi tanaman, $\mathrm{TD}=$ tinggi dikotomus, $\mathrm{DB}=$ diameter batang, $\mathrm{PD}=$ panjang daun, $\mathrm{LD}=$ lebar daun, $\mathrm{UB}$ $(\mathrm{HST})=$ umur berbunga, $\mathrm{UP}=$ umur panen $(\mathrm{HST})$

Tabel 5. Nilai pengamatan panjang buah, diameter buah, panjang tangkai buah, bobot per buah, bobot buah pertanaman, dan jumlah buah per tanaman

\begin{tabular}{lcccccc}
\hline \multicolumn{1}{c}{ Genotipe } & PB $(\mathrm{cm})$ & DB $(\mathrm{cm})$ & PTB $(\mathrm{cm})$ & BPB $(\mathrm{g})$ & BBT $(\mathrm{g})$ & JBT \\
\hline GJ & $21.36 \mathrm{~cd}$ & $3.54 \mathrm{~g}$ & $3.07 \mathrm{fg}$ & $105.42 \mathrm{~d}$ & $248.9 \mathrm{def}$ & $2.25 \mathrm{de}$ \\
$2016-056$ & $24.44 \mathrm{abc}$ & $4.73 \mathrm{def}$ & $3.89 \mathrm{cdefg}$ & $183.69 \mathrm{c}$ & $791.7 \mathrm{bcdef}$ & $4.28 \mathrm{cde}$ \\
$2016-076$ & $5.76 \mathrm{f}$ & $3.84 \mathrm{~g}$ & $3.62 \mathrm{efg}$ & $24.32 \mathrm{f}$ & $123.7 \mathrm{f}$ & $5.50 \mathrm{~cd}$ \\
$2016-084$ & $21.98 \mathrm{bcd}$ & $4.89 \mathrm{cde}$ & $3.90 \mathrm{cdefg}$ & $172.57 \mathrm{c}$ & $1347.0 \mathrm{ab}$ & $7.80 \mathrm{bc}$ \\
$2016-002$ & $8.10 \mathrm{f}$ & $6.19 \mathrm{~b}$ & $3.46 \mathrm{efg}$ & $81.56 \mathrm{de}$ & $561.7 \mathrm{cdef}$ & $6.62 \mathrm{bc}$ \\
$2016-004$ & $26.29 \mathrm{ab}$ & $5.67 \mathrm{bc}$ & $5.58 \mathrm{~b}$ & $241.40 \mathrm{~b}$ & $984.0 \mathrm{bcd}$ & $3.96 \mathrm{cde}$ \\
$2016-005$ & $13.63 \mathrm{e}$ & $5.04 \mathrm{cde}$ & $3.22 \mathrm{fg}$ & $113.74 \mathrm{~d}$ & $611.1 \mathrm{cdef}$ & $6.33 \mathrm{bc}$ \\
$2016-008$ & $20.41 \mathrm{~cd}$ & $4.26 \mathrm{efg}$ & $5.13 \mathrm{bcd}$ & $109.42 \mathrm{~d}$ & $653.9 \mathrm{bcdef}$ & $6.58 \mathrm{bc}$ \\
$2016-011$ & $24.35 \mathrm{abc}$ & $3.95 \mathrm{fg}$ & $2.49 \mathrm{~g}$ & $26.78 \mathrm{f}$ & $366.0 \mathrm{def}$ & $13.67 \mathrm{a}$ \\
$2016-015$ & $27.40 \mathrm{a}$ & $4.97 \mathrm{cde}$ & $4.82 \mathrm{bcde}$ & $216.51 \mathrm{bc}$ & $956.4 \mathrm{bcde}$ & $4.45 \mathrm{cde}$ \\
$2016-039$ & $6.18 \mathrm{f}$ & $5.20 \mathrm{~cd}$ & $8.97 \mathrm{a}$ & $173.42 \mathrm{c}$ & $231.2 \mathrm{ef}$ & $1.33 \mathrm{e}$ \\
$2016-080$ & $20.74 \mathrm{~cd}$ & $5.38 \mathrm{~cd}$ & $3.72 \mathrm{defg}$ & $169.71 \mathrm{c}$ & $1196.2 \mathrm{bc}$ & $6.70 \mathrm{bc}$ \\
$2016-026$ & $18.34 \mathrm{~d}$ & $9.90 \mathrm{a}$ & $5.29 \mathrm{bc}$ & $369.86 \mathrm{a}$ & $1884.7 \mathrm{a}$ & $4.92 \mathrm{cde}$ \\
JAFANA & $24.04 \mathrm{abc}$ & $4.93 \mathrm{cde}$ & $4.11 \mathrm{cdef}$ & $178.61 \mathrm{c}$ & $941.6 \mathrm{bcde}$ & $5.21 \mathrm{cde}$ \\
PIPIT & $7.23 \mathrm{f}$ & $5.05 \mathrm{cde}$ & $3.34 \mathrm{fg}$ & $48.97 \mathrm{ef}$ & $465.7 \mathrm{cdef}$ & $9.50 \mathrm{~b}$ \\
\hline
\end{tabular}

Keterangan : Angka yang diikuti oleh huruf kecil yang sama pada kolom yang sama menunjukkan tidak berbeda nyata pada taraf uji $\alpha=5 \%$. PB = Panjang buah, $\mathrm{DB}=$ diameter buah, $\mathrm{PTB}=$ panjang tangkai buah, $\mathrm{BPB}=$ bobot per buah, $\mathrm{BBT}=$ bobot buah per tanaman, JBT $=$ jumlah buah per tanaman 
Tabel 6. Korelasi antar karakter kuantitatif

\begin{tabular}{lcccccccccccc}
\hline & TTN & TD & DBT & PHD & LD & UB & UP & PBU & DBU & PTB & BPB & JBT \\
\hline TD & $0.66^{* *}$ & & & & & & & & & & & \\
DBT & $0.60^{* *}$ & $0.40^{*}$ & & & & & & & & & & \\
PHD & $0.55^{* *}$ & $0.52^{* *}$ & $0.78^{* *}$ & & & & & & & & & \\
LD & $0.50^{* *}$ & 0.35 & $0.68^{* *}$ & $0.84^{* *}$ & & & & & & & & \\
UB & $0.56^{* *}$ & $0.06^{\text {tn }}$ & $0.46^{* *}$ & $0.38^{* *}$ & $0.48^{* *}$ & & & & & & & \\
UP & $0.12^{\text {tn }}$ & $-0.06^{\text {tn }}$ & $0.32^{*}$ & $0.34^{*}$ & $0.37^{* *}$ & $0.44^{* *}$ & & & & & & \\
PBU & $0.19^{\text {tn }}$ & $0.39^{* *}$ & $0.28^{*}$ & $0.62^{* *}$ & $0.54^{* *}$ & $-0.02^{\text {tn }}$ & $0.05^{\text {tn }}$ & & & & & \\
DBU & $0.21^{\text {tn }}$ & $0.15^{\text {tn }}$ & $0.62^{* *}$ & $0.51^{* *}$ & $0.39^{* *}$ & $0.33^{*}$ & $0.14^{\text {tn }}$ & $0.01^{\text {tn }}$ & & & & \\
PTB & $0.47^{* *}$ & $0.48^{* *}$ & $0.39^{* *}$ & $0.61^{* *}$ & $0.56^{* *}$ & $0.50^{* *}$ & $0.01^{\text {tn }}$ & $0.46^{* *}$ & $0.25^{\text {tn }}$ & & & \\
BPB & $0.28^{*}$ & $0.34^{*}$ & $0.67^{* *}$ & $0.81^{* *}$ & $0.66^{* *}$ & $0.20^{\text {tn }}$ & $0.22^{\text {tn }}$ & $0.65^{* *}$ & $0.72^{* *}$ & $0.42^{* *}$ & & \\
JBT & $-0.01^{\text {tn }}$ & $0.05^{\text {tn }}$ & $-0.02^{\text {tn }}$ & $-0.10^{\text {tn }}$ & $-0.17^{\text {tn }}$ & $-0.07^{\text {tn }}$ & $0.22^{\text {tn }}$ & $0.38^{* *}$ & $-0.01^{\text {tn }}$ & $-0.32^{*}$ & $-0.24 \operatorname{tn}$ & \\
BBT & $0.2^{\text {nn }}$ & $0.37^{* *}$ & $0.60^{* *}$ & $0.62^{* *}$ & $0.41^{* *}$ & $0.02^{\text {tn }}$ & $0.26^{\text {tn }}$ & $0.35^{*}$ & $0.56^{* *}$ & $0.10^{\text {tn }}$ & $0.71^{* *}$ & $0.37^{* *}$ \\
\hline
\end{tabular}

Keterangan $: * *=$ berkorelasi sangat nyata; $*=$ berkorelasi nyata; $\mathrm{tn}=$ tidak nyata; $\mathrm{TTN}=$ tinggi tanaman; TD= tinggi dikotomus; $\mathrm{DBT}=$ diameter batang; $\mathrm{PHD}=$ panjang helai daun; $\mathrm{LD}=$ lebar daun; $\mathrm{UB}=$ umur berbunga; $\mathrm{UP}=$ umur panen; $\mathrm{PBU}=$ panjang buah; $\mathrm{DBU}=$ diameter buah; $\mathrm{PTB}=$ panjang tangkai buah; $\mathrm{BPB}=$ bobot per buah; JBT= jumlah buah per tanaman; $\mathrm{BBT}=$ bobot buah per tanaman

tangkai buahnya berkisar antara $3.07-5.58 \mathrm{~cm}$. Karakter jumlah buah per tanaman juga memiliki keragaman, dengan nilai tengah berkisar antara 1.33-13.67 buah (Tabel 5). Genotipe 2016-039 dan GJ memiliki nilai tengah jumlah buah per tanaman paling sedikit berturut-turut adalah 1.33 dan 2.25 buah. Hal tersebut terjadi karena tanaman terserang penyakit layu bakteri sehingga tanaman layu dan mati setelah berbuah satu kali. Nilai tengah jumlah buah per tanaman yang paling banyak adalah genotipe 2016-011.

Nilai tengah bobot per buah yang diuji berkisar antara 24.32-369.86 gram (Tabel 5). Genotipe 2016-076 dan 2016011 memiliki nilai tengah bobot per buah terendah berturut-

\section{Tingkat Persentase kejadian penyakit}

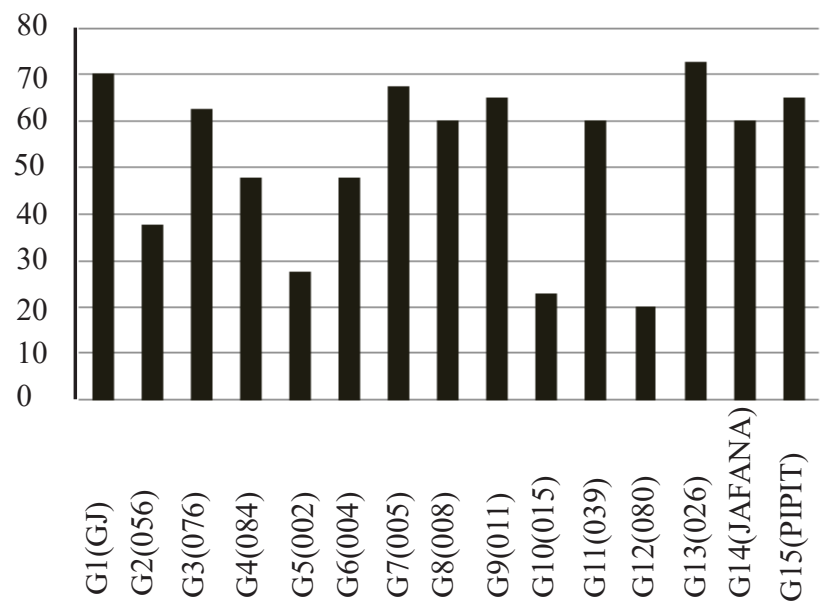

Gambar 1. Persentase kejadian penyakit 15 genotipe terung pada minggu ke-8 turut adalah 24.32 dan 26.78 gram. Hal tersebut karena rasio panjang per diameter buahnya kecil dan sangat kecil. Nilai tengah bobot per buah tertinggi yaitu genotipe 2016026. Karakter bobot buah per tanaman memiliki keragaman dengan nilai tengah berkisar antara 123.7-1884.7 gram (Tabel 5). Genotipe 2016-076 memiliki nilai tengah bobot buah per tanaman terendah yaitu 123.7 gram. Genotipe 2016-026 memiliki nilai tengah bobot buah per tanaman tertinggi yaitu 1884.7 gram. Menurut penelitian Angio (2016) suhu tinggi dapat menurunkan tinggi tanaman, jumlah daun, jumlah cabang, sehingga menurunkan jumlah bunga, viabilitas polen, jumlah buah, panjang buah, dan bobot buah per tanaman terung.

\section{Korelasi antar Karakter Kuantitatif}

Hasil pengujian analisis korelasi antar karakter kuantitatif terdapat pada Tabel 6. Tinggi tanaman berkorelasi sangat nyata terhadap tinggi dikotomus, diameter batang, panjang helai daun, lebar daun, umur bebunga, dan panjang tangkai buah. Umur berbunga berkorelasi positif sangat nyata terhadap umur panen. Aprilia (2014) yang menyatakan bahwa umur berbunga berkorelasi positif sangat nyata terhadap umur panen.

Bobot per buah berkorelasi positif sangat nyata terhadap panjang buah dan diameter buah. Hal tersebut juga dibuktikan oleh penelitian Widia (2016) yang menyatakan bahwa karakter bobot per buah berkorelasi positif sangat nyata terhadap panjang buah dan diameter buah. Jumlah buah pertanaman tidak berkorelasi terhadap bobot per buah, namun berkorelasi positif sangat nyata terhadap bobot buah per tanaman. Hal tersebut menunjukkan bahwa genotipe terung yang memiliki jumlah buah per tanaman yang banyak 
memiliki kecenderungan nilai bobot buah per tanaman yang tinggi. Hasil yang berbeda ditunjukkan oleh penelitian Aprilia (2014) yang menyatakan bahwa nilai jumlah buah per tanaman tinggi memiliki kecenderungan nilai bobot buah per tanaman rendah.

\section{Tingkat Kejadian Penyakit}

Menurut EPPO (2004) penyakit layu bakteri sering menyerang pada komoditas bernilai ekonomis tinggi seperti kacang tanah (Arachis hypogea), tomat (Lycopersicon esculentum), tembakau (Nicotiana tabacum), terung (Solanum melongena), dan kentang (Solanum tuberosum). Penyakit ini disebabkan oleh bakteri Ralstonia solanacearum dengan gejala yang ditimbulkan yaitu tanaman mendadak layu (Rizky, 2013). Gejala penyakit layu bakteri mulai terlihat pada minggu kelima setelah tanam. Penyakit layu bakteri menyerang semua genotipe tanaman terung dengan rentang 20-72.5 \% (Gambar 1). Genotipe 2016-080 dan 2016-015 adalah genotipe yang memiliki nilai kejadian penyakit paling rendah berturut-turut $20 \%$ dan $22.5 \%$. Genotipe 2016-026 dan GJ merupakan genotipe yang persentase kejadian penyakitnya paling tinggi, berturut-turut adalah 72.5\% dan 70\%. Genotipe 2016-002 memiliki tingkat kejadian penyakit yang lebih kecil dibandingkan dengan varietas pembanding Pipit. Genotipe 2016-084 memiliki tingkat kejadian penyakit yang lebih rendah dibandingkan dengan varietas pembanding Jafana.

\section{KESIMPULAN}

Terdapat keragaman karakter kualitatif pada fase kecambah, pertumbuhan tanaman, batang, helai daun, bunga dan buah. Karakter kuantitatif menunjukkan adanya keragaman. Genotipe 2016-026, 2016-080, 2016-084, 2016004, dan 2016-015 memiliki bobot buah per tanaman yang lebih tinggi dibandingkan dengan varietas pembanding JAFANA. Genotipe 2016-002 juga memiliki bobot buah per tanaman yang lebih tinggi dibandingkan varietas PIPIT. Genotipe yang mengalami tingkat kejadian penyakit terendah adalah 2016-080, 2016-015, dan 2016-002.

\section{DAFTAR PUSTAKA}

Angio, M. H. 2016. Respon fisiologi dan morfologi tanaman terung (Solanum melongena) terhadap cekaman suhu tinggi. Tesis. Institut Pertanian Bogor. Bogor.

Aprilia, I. 2014. Karakterisasi 18 genotipe terung (Solanum melongena L.). Skripsi. Institut Pertanian Bogor. Bogor.

Ashari, S. 1995. Hortikultura Aspek Budidaya. Universitas Indonesia Press. Jakarta.

[BMKG] Badan Meteorologi Klimatologi dan Geofisika. 2017. Data iklim Bogor bulan Januari-Mei 2017. Stasiun Klimatologi Dramaga Bogor. Bogor.
[BPS] Badan Pusat Satistik. 2014. Luas Lahan Sawah (Hektar). http://www.bps.go.id. [15 Agustus 2017].

[Ditjen Hortikultura] Direktorat Jenderal Hortikultura. 2015. Statistik Produksi Hortikultura Tahun 2014. http://Hortikultura.pertanian.go.id/wp-content/ uploads/2016/02/Statistik-Produksi-2014.pdf. [23 Januari 2017].

[EPPO] Europen Plant Protection Organization. 2004. Diagnostic Protocols for Regulated Pests Rolstania solanacearum. Bulletin 34: 173-178.

[FAO] Food and Agriculture Organization. 2016. Explore Data. http://www.fao.org/faostat/en\#data/QC. [3 Februari 2017].

Khasanah, U. 2013. Evaluasi karakter daya hasil beberapa genotipe tomat (Lycopersicon esculentum Mill.) di Kebun Percobaan IPB Tajur. Skripsi. Institut Pertanian Bogor. Bogor.

[PPVT] Pusat Perlindungan Varietas Tanaman. 2007. Panduan pengujian individual kebaruan, keunikan, keseragaman, dan kestabilan terung (Solanum melongena). PVT/PPI/23/1.

Rizky, M.S. 2013. Hama dan Penyakit Tanaman Terung (Solanum melongena L.) di Kecamatan Rancabungur, Kabupaten Bogor. Skripsi. Institut Pertanian Bogor. Bogor.

Rubatzky, V.E., Yamaguchi, M. 1999. Sayuran dunia 3: prinsip, produksi, dan gizi, Edisi Kedua. Terjemahan dari : World Vegetables: Principles, Production, and Nutritive Values, Second Edition. ITB Bandung. Bandung.

Safei, M., A. Rahmi, N. Jannah. 2014. Pengaruh jenis dan dosis pupuk organik terhadap pertumbuhan dan hasil tanaman terung (Solanum melongena L.) varietas Mustang F-1.Jurnal Agrifor 13(1):59-66.

Syukur, M., S. Sujiprihati, R. Yunianti. 2012. Teknik Pemuliaan Tanaman. Penebar Swadaya. Bogor.

[USDA] United States Departement of Agriculture. 2016. National Nutrient Database for Standard Reference. https://ndb.nal.usda.gov/ndb/foods/show/2962.[9 Maret 2017].

Wahyudi. 2011. Meningkatkan Hasil Panen Sayuran dengan Teknologi EMP. Agromedia Pustaka. Jakarta.

Widia, T. 2016. Karakterisasi dan ketahanan terhadap layu bakteri (Ralstonia solanacearum) 20 genotipe terung (Solanum melongena L.). Skripsi. Instiut Pertanian Bogor. Bogor. 